\title{
ISOLASI PROTEIN KACANG MERAH DAN KACANG HIJAU MENGGUNAKAN METODE ASAM BASA DIKOMBINASIKAN DENGAN PROSES ENZIMATIS
}

\author{
[Isolation of Protein from Red Beans and Green Beans using Acid-Base Method \\ Combined with Enzymatic Processes]
}

\author{
Slamet Hadi Kusumah"), Robi Andoyo ${ }^{2) \star}$, dan Tita Rialita ${ }^{2)}$ \\ 1) Program Studi Teknologi Pangan, Fakultas Teknik, Universitas Islam Al-Ihya, Kuningan \\ 2) Departemen Teknologi Pangan, Fakultas Teknologi Industri Pertanian, Universitas Padjadjaran, Bandung
}

Diterima 16 Januari 2021 / Disetujui 8 Desember 2021

\begin{abstract}
Red beans (Phaseolus vulgaris L.) and greens beans (Phaseolus raditus L.) proteins contain high amount of essential amino acids lysine and leucine. The study aimed to determine the optimum conditions for protein isolation process from red beans and green beans flour to produce the highest protein content. Additionally, an enzymatic hydrolysis was aimed to produce isolates or protein concentrates of red beans and green beans with good digestibility. The research method used was the Response Surface Methodology (RSM) Box-Behnken Design with Design Expert 10. The variables used in this process were extraction temperature $\left(30-50^{\circ} \mathrm{C}\right)$, extraction $\mathrm{pH}$ (8.50-9.50), and time extraction (30-60 minutes). The results showed that the optimum conditions for the extraction of red beans protein were extraction $\mathrm{pH}$ of 8.60 , temperature of $30^{\circ} \mathrm{C}$, and time of 30.1 minutes, with the resulting protein content of $86.88 \pm 1.38 \%$ with and a validity value of 0.91 . Meanwhile, the optimum conditions for the green beans protein extraction process were extraction $\mathrm{pH}$ of 8.83 , extraction temperature of $30^{\circ} \mathrm{C}$, extraction time of 30 minutes which yielded protein content of $88.27 \pm 1.08 \%$ and a validity value of 0.97 . Enzymatic hydrolysis using of $3 \%$ $(w / w)$ bromelain enzyme on red bean and mung bean protein concentrate powder was able to increase protein digestibility by 15.61 and $14.51 \%$, respectively.
\end{abstract}

Keywords: concentrate protein, enzymatic hydrolysis, protein isolation

\begin{abstract}
ABSTRAK
Protein kacang merah (Phaseolus vulgaris L.) dan kacang hijau (Phaseolus raditus L.) memiliki asam amino esensial lisin dan leusin yang tinggi. Penelitian ini bertujuan untuk mengetahui kondisi optimum proses isolasi protein tepung kacang merah dan kacang hijau yang menghasilkan kadar protein tertinggi. Tahap modifikasi hidrolisis enzimatis bertujuan untuk menghasilkan isolat atau konsentrat protein kacang merah dan kacang hijau dengan daya cerna protein yang baik. Penelitain ini menggunakan metode Response Surface Methodology (RSM) Box-Behnken Design melalui Software Desain Expert 10. Variabel yang digunakan pada proses ini adalah suhu ekstraksi $\left(30-50^{\circ} \mathrm{C}\right), \mathrm{pH}$ ekstraksi $(8,50-9,50)$, dan lama ekstraksi (30-60 menit). Hasil penelitian menunjukkan bahwa kondisi optimum proses ekstraksi protein kacang merah dilakukan pada $\mathrm{pH}$ ekstraksi 8,60 , suhu ekstraksi $30^{\circ} \mathrm{C}$, lama ekstraksi 30,1 menit, dan menghasilkan kadar protein $86,88 \pm 1,38 \%$ dengan nilai validitas 0,91 . Kondisi optimum proses ekstraksi protein kacang hijau dilakukan pada $\mathrm{pH}$ ekstraksi 8,83 , suhu ekstraksi $30^{\circ} \mathrm{C}$, lama ekstraksi 30 menit dan menghasilkan kadar protein $88,27 \pm 1,08 \%$ dengan nilai validitas 0,97 . Hidrolisis enzimatis dengan penambahan enzim bromelin $3 \%(\mathrm{~b} / \mathrm{b})$ pada bubuk konsentrat protein kacang merah dan kacang hijau mampu meningkatkan daya cerna protein berturut-turut sebesar 15,61 dan 14,51\%.
\end{abstract}

Kata kunci: hidrolisis enzimatis, isolasi protein, konsentrat protein

*Penulis Korespondensi: E-mail: r.andoyo@unpad.ac.id 


\section{PENDAHULUAN}

Persentase stunting di Jawa Barat saat ini adalah $34,51 \%$ yang tersebar di beberapa Kabupaten diantaranya Sukabumi, Cianjur, Cirebon dan Garut (Yusuf et al., 2018). Stunting didefinisikan sebagai keadaan dengan tinggi badan di bawah 2 simpang baku dari median pada kurva pertumbuhan tinggi badan. Penyebab dan faktor risiko stunting terjadi karena faktor internal seperti genetik ataupun eksternal seperti asupan nutrisi kurang dan infeksi kronis. Anak balita stunting lebih rendah mengonsumsi protein dibandingkan anak balita dengan status gizi baik (Ernawati et al., 2016). Anak-anak dengan status gizi baik mempunyai asam amino esensial seperti lisin dan leusin yang lebih tinggi dibandingkan dengan anak stunting (Semba et al., 2016).

Komoditas lokal Jawa Barat yang berpotensi sebagai sumber protein nabati (plant-based protein) adalah kacang merah dan kacang hijau dengan kadar protein masing-masing sekitar 22 dan 20\% (Kusumah et al., 2020a). Kandungan asam amino esensial biji kacang merah dan kacang hijau cukup lengkap, yakni isoleusin, leusin, lisin, metionin, fenilalanin, threonin, dan valin (Almatsier, 2013). Pada penelitian sebelumnya (Kusumah et al., 2020a), telah dilakukan identifikasi asam amino pada tepung kacang merah dan kacang hijau. Asam amino esensial terbesar yang terdapat pada tepung kacang merah dan tepung kacang hijau adalah lisin sebesar $15.929,89$ dan $14.916,14 \mathrm{mg} / \mathrm{kg}$, kemudian terbesar kedua adalah leusin sebesar 12.385,81 dan $12.694,86 \mathrm{mg} / \mathrm{kg}$, masing-masing (Kusumah et al., 2020a). Hasil tersebut memberikan penguatan bahwa protein kacang merah dan kacang hijau berpotensi untuk menjadi sumber asam amino esensial pada berbagai macam produk high protein food.

Protein kacang merah dan kacang hijau dapat diisolasi dan diolah menjadi bubuk isolat atau konsentrat protein (Gunarti et al., 2013; Wang et al., 2011; Zhu et al., 2018). Isolat atau konsentrat protein kacang merah dan kacang hijau diperoleh dengan cara mengendapkan protein pada titik isoelektriknya. Berdasarkan penelitian sebelumnya (Kusumah et al., 2020a), telah diidentifikasi titik isoelektrik kacang merah dan kacang hijau yaitu masing-masing $\mathrm{pH} 4,56$ dan 4,81.

Isolasi protein kacang-kacangan menggunakan metode asam basa dimulai dengan proses ekstraksi protein pada larutan alkali. Pada kondisi basa, proses ekstraksi menghasilkan protein yang lebih banyak karena protein yang terlarut mudah dipisahkan dari residu. Kondisi basa juga dapat merusak asam amino yang mengandung sulfur diantaranya triptofan, treonin, lisin, dan metionin (Kanetro, 2017). Penggunaan variasi suhu pemanasan dan lama ekstraksi dalam teknik isolasi protein kacang-kacang juga menentukan rendemen isolat atau konsentrat protein yang dihasilkan. Proses ekstraksi protein kacang merah dan kacang hijau yang dilakukan pada suhu suhu ruang selama 30 menit dan $\mathrm{pH}$ ekstraksi 9,00 menghasilkan rendemen protein sebesar 81,87 dan $76,99 \%$, masingmasing (Kusumah et al., 2020b). Kondisi ekstraksi ini perlu dioptimasi agar bisa menghasilkan isolat atau konsentrat protein yang lebih banyak.

Tantangan dari penelitian ini adalah mendapatkan konsentrat atau isolat protein kacang merah dan kacang hijau dengan profil yang baik seperti bentuk oligopeptida (2-10 asam amino) sehingga dapat memperbaiki daya cerna protein. Teknik yang dapat dilakukan yaitu melalui proses isolasi protein kacang-kacangan yang dikombinasikan dengan proses hidrolisis enzimatis (Kusumah et al., 2020b). Enzim protease dapat mengubah protein dari bentuk kompleks menjadi bentuk sederhana yang diharapkan mampu menghasilkan daya cerna protein yang lebih baik. Konsentrasi enzim alcalase optimal pada proses isolasi protein kacang adalah $4 \%$ dengan dosis $3642 \mathrm{U} / \mathrm{g}$ menghasilkan soy bean oligopeptides (Cai et al., 2014). Proses isolasi kacang merah dengan penambahan enzim protease sebesar 3\% menghasilkan bubuk konsentrat protein dengan kadar protein sebesar 73,34\% (Liu et al., 2011). Isolasi protein kacang kedelai dengan penambahan enzim Corolase PP (10 mg enzyme/g SPI) menghasilkan soy bean oligopeptides yang memiliki sifat fungsional ACE inhibitor, peptide antithrombotic dan antioxidative (Coscueta et al., 2019).

Penelitian ini bertujuan untuk mendapatkan kondisi optimum isolasi protein tepung kacang merah dan kacang hijau yang menghasilkan kadar protein tertinggi. Tahap modifikasi hidrolisis enzimatis dengan penambahan enzim bromelin bertujuan untuk menghasilkan isolat atau konsentrat protein kacang merah dan kacang hijau dengan daya cerna yang baik. Enzim bromelin memiliki sifat karakteristik yaitu titik isoelektrik berada pada $\mathrm{pH}$ 9,5, suhu optimum berkisar antara $50^{\circ} \mathrm{C}$, aktivitas spesifik 5-10 U/mg protein dan berwarna putih sampai kekuning-kuningan dengan bau khas. Enzim bromelin lebih mudah didapatkan dan memiliki harga yang lebih murah dibandingkan dengan enzim protease lainnya.

\section{BAHAN DAN METODE}

\section{Bahan}

Bahan yang digunakan dalam proses isolasi protein adalah kacang merah (Phaseolus vulgaris L.) (Argapura, Kabupaten Majalengka), kacang hijau (Phaseolus raditus L.) (Ciwaringin, Kabupaten Cirebon), akuades, asam klorida ( $\mathrm{HCl}) 2 \mathrm{~N}$ (merck), 
natrium hidroksida $(\mathrm{NaOH})$ 0,5 N (merck), bromelain enzyme (focusherb, Cina).

\section{Pembuatan tepung kacang merah dan tepung kacang hijau (Pangastuti et al., 2013)}

Persiapan bahan baku yang dilakukan pada penelitian ini adalah proses penepungan biji kacang merah dan kacang hijau. Tahap ini diawali dengan pencucian dan sortasi kacang merah dan kacang hijau menggunakan ari bersih. Tujuannya adalah membersihkan dan memisahkan bagian kacang merah atau kacang hijau dari kontaminan. Selanjutnya, proses perendaman selama 11 jam menggunakan akuades untuk menginaktifkan asam fitat yang terdapat pada bagian kulit ari kacang merah dan kacang hijau. Kacang merah dan kacang hijau dikeringkan menggunakan sinar matahari selama 1-2 hari sampai kadar air $<15 \%$. Kacang merah dan kacang hijau yang sudah kering kemudian dilakukan penggilingan menggunakan discmill (FFC-23, Cina). Pengayakan tepung kacang merah dan kacang hijau menggunakan saringan 80 mesh.

\section{Optimasi proses ekstraksi protein (Wang et al., 2011)}

Metode penelitian Response Surface Methodology (RSM) Box-Behnken Design melalui Software Desain Expert 10 dipilih untuk mengoptimasi kondisi proses ekstraksi protein kacang merah dan kacang hijau. Variabel yang digunakan pada proses ini adalah suhu ekstraksi $\left(30-50^{\circ} \mathrm{C}\right), \mathrm{pH}$ ekstraksi (8,50-9,50), dan lama ekstraksi (30-60 menit). Variabel bebas ditentukan berdasarkan trial and error dan kajian penelitian sebelumnya (Kusumah et al., 2020b) untuk menentukan batas minimum dan maksimum. Berdasarkan program Desain Expert RSM Box-Behnken Design diperoleh 17 perlakuan dengan berbagai kombinasi suhu ekstraksi, $\mathrm{pH}$ ekstraksi, dan lama ekstraksi (Tabel 1). Respon yang diukur dan dioptimasi adalah kadar protein per total solid (\%) menggunakan metode kjeldahl (buchi, Swiss) (AOAC, 1990).

Isolasi protein kacang merah dan kacang hijau menggunakan metode asam basa yaitu melalui proses ekstraksi dan pengendapan memodifikasi teknik yang dilakukan oleh Wang et al. (2011). Setiap formula dibuat dari $40 \mathrm{~g}$ tepung kacang merah atau tepung kacang hijau. Pencampuran bahan dengan rasio tepung kacang merah:akuades adalah 1:10 (b/b). Kemudian diaduk selama 3 menit dan dilakukan pengecekan $\mathrm{pH}$ awal menggunakan $\mathrm{pH}$ meter (lutron $\mathrm{pH} 208$ portable). Hal yang sama juga dilakukan pada sampel tepung kacang hijau.

Proses selanjutnya adalah penyesuaian $\mathrm{pH}$ dengan menambahkan $\mathrm{NaOH} 0,5 \mathrm{~N}$ sampai $\mathrm{pH}$ menunjukkan nilai $\mathrm{pH}$ ekstraksi sesuai rancangan penelitian. Proses sentrifugasi I (Thermo scientific ST16 benchtop centrifuge, Jerman) dilakukan selama 15 menit pada kecepatan 4000-4500 rpm, tujuannya adalah untuk memisahkan residu yang mengendap dan supernatan (protein yang terlarut). Supernatan kemudian diambil untuk proses pengendapan. Supernatan ditambahkan $\mathrm{HCl} 2 \mathrm{~N}$ sampai $\mathrm{pH}$ menunjukkan $\mathrm{pH}$ isoelektrik (pl) yaitu $\mathrm{pH}$ 4,56 (kacang merah) dan $\mathrm{pH} 4,81$ (kacang hijau) (Kusumah et al., 2020a). Proses pengendapan dilakukan pada suhu $30^{\circ} \mathrm{C}$ selama 10 menit. Proses sentrifugasi II dilakukan selama 15 menit pada kecepatan 4000$4500 \mathrm{rpm}$. Endapan protein yang dihasilkan kemudian dilakukan uji kadar protein dengan metode Kjeldahl.

Analisis respon dilakukan dengan menggunakan beberapa pilihan model analysis of variance (ANOVA) yaitu linear, quadratic, dan cubic. Pemilihan model ini ditentukan berdasarkan model yang memberikan nilai terbesar, menghasilkan nilai signifikansi ANOVA, dan non signifikansi pada lack of fit (Apriliyanti et al., 2020).

Tabel 1. Data formulasi kondisi proses ekstraksi dan data respon kadar protein (\%)

\begin{tabular}{cccccc}
\multirow{2}{*}{ Run } & $\begin{array}{c}\text { Faktor A } \\
\text { Suhu Ekstraksi }\left({ }^{\circ} \mathrm{C}\right)\end{array}$ & $\begin{array}{c}\text { Faktor B } \\
\text { pH Ekstraksi }\end{array}$ & $\begin{array}{c}\text { Faktor C } \\
\text { Lama Ekstraksi (Menit) }\end{array}$ & \multicolumn{2}{c}{ Respon Kadar Protein per Total Solid (\%) } \\
\cline { 5 - 6 } & 30 & 8,50 & 45 & Kacang Merah & Kacang Hijau \\
2 & 30 & 9,00 & 30 & $86,53 \pm 1,15$ & $85,36 \pm 2,96$ \\
3 & 30 & 9,00 & 60 & $86,98 \pm 0,05$ & $89,93 \pm 5,96$ \\
4 & 30 & 9,50 & 45 & $87,37 \pm 6,34$ & $89,64 \pm 0,60$ \\
5 & 40 & 8,50 & 30 & $89,42 \pm 2,74$ & $86,49 \pm 6,24$ \\
6 & 40 & 8,50 & 60 & $93,20 \pm 0,87$ & $91,59 \pm 1,57$ \\
7 & 40 & 9,00 & 45 & $75,71 \pm 7,40$ & $91,38 \pm 2,98$ \\
8 & 40 & 9,00 & 45 & $90,60 \pm 5,16$ & $84,40 \pm 2,73$ \\
9 & 40 & 9,00 & 45 & $76,74 \pm 8,11$ & $92,44 \pm 0,27$ \\
10 & 40 & 9,00 & 45 & $68,95 \pm 9,50$ & $90,26 \pm 8,01$ \\
11 & 40 & 9,00 & 45 & $74,66 \pm 3,10$ & $82,64 \pm 4,70$ \\
12 & 40 & 9,50 & 30 & $59,78 \pm 8,50$ & $86,47 \pm 2,27$ \\
13 & 40 & 9,50 & 60 & $77,90 \pm 8,34$ & $78,02 \pm 0,88$ \\
14 & 50 & 8,50 & 45 & $76,07 \pm 3,90$ & $81,99 \pm 2,87$ \\
15 & 50 & 9,00 & 30 & $48,14 \pm 1,50$ & $85,58 \pm 10,06$ \\
16 & 50 & 9,00 & 60 & $53,09 \pm 6,41$ & $76,51 \pm 5,10$ \\
17 & 50 & 9,50 & 45 & $53,42 \pm 2,91$ & $88,42 \pm 6,70$ \\
\hline
\end{tabular}


Program Desain Expert 10 juga memberikan fitur grafik contour plot yang menunjukkan kombinasi antar komponen yang saling memengaruhi nilai respon dengan warna biru (nilai respon terendah) dan warna merah (nilai respon tertinggi). Bentuk permukaan dari hubungan interaksi antar komponen ini dapat dilihat lebih jelas pada grafik tiga dimensi (3-D) (Braimah et al., 2016). Formula dengan nilai desirability maksimum dipilih karena menunjukkan kemampuan Program Desain Expert 10 untuk memberikan nilai yang dikehendaki. Solusi yang dilakukan jika nilai desirability sama adalah memilih nilai respon yang paling tinggi (Maula et al., 2019).

Tahap verifikasi atau validasi dilakukan dengan cara mengisolasi protein sesuai dengan kombinasi suhu ekstraksi, pH ekstraksi, dan lama ekstraksi terbaik dan menganalisis kadar protein per total solid (\%). Verifikasi dilakukan dengan dua kali ulangan. Nilai validitas diukur dengan membandingkan nilai aktual dan nilai prediksi (Anihouvi et al., 2011). Apabila terdapat kesesuaian antara nilai aktual dan nilai prediksi maka verifikasi dinyatakan baik (Muhandri et al., 2017).

\section{Modifikasi hidrolisis enzimatis (Liu et al., 2011; Wang et al., 2016)}

Modifikasi hidrolisis enzimatis bertujuan untuk menghasilkan konsentrat dengan bentuk oligopeptida sehingga memiliki daya cerna protein yang baik. Proses ini hanya menggunakan endapan terbaik yang dihasilkan pada tahap sebelumnya. Proses ini memodifikasi teknik yang telah dilakukan oleh Liu et al. (2011) dan Wang et al. (2016).

Endapan protein kacang merah dan kacang hijau terbaik dikeringkan menggunakan alat pengering freeze dryer (christ alpha 1-4 LD plus) pada suhu kurang lebih $-50^{\circ} \mathrm{C}$ selama 24 jam. Bubuk konsentrat atau isolat yang telah kering kemudian dicampurkan dengan akuades. Rasio bubuk isolat atau konsentrat protein kacang merah:akuades adalah 1:5 (b/b). Rasio yang sama juga dilakukan pada bubuk isolat atau konsentrat protein kacang hijau.

Proses selanjutnya adalah penyesuaian $\mathrm{pH}$ dengan menambahkan $\mathrm{NaOH} 0,5 \mathrm{~N}$ sampai $\mathrm{pH}$ menunjukkan nilai $\mathrm{pH}$ 8,00 dan pemanasan sampai suhu $50^{\circ} \mathrm{C}$. Pemberian enzim bromelin dengan konsentrasi 3\% (b/b) dari berat bubuk kosentrat protein yang digunakan. Tahap selanjutnya dilakukan proses hidrolisis selama 60 menit. Kemudian proses inaktivasi enzim dengan cara pemanasan selama 15 menit pada suhu $90^{\circ} \mathrm{C}$. Sentrifugasi dilakukan pada kecepatan 4000-4500 rpm selama 15 menit. Endapan yang dihasilkan kemudian dikeringkan menggunakan freeze drayer pada suhu kurang lebih $-50^{\circ} \mathrm{C}$ selama 24 jam. Kosentrat protein kacang merah dan kacang hijau terhidrolisis enzimatis kemudian dilakukan pengamatan yaitu kadar air meto- de gravimetri (AOAC, 1990), kadar protein metode kjeldhal (AOAC, 1990), dan uji daya cerna protein metode in vitro (Saunders et al., 1973).

\section{Pengujian daya cerna metode in vitro (Saunders et al., 1973)}

Penentuan daya cerna protein dilakukan dengan mengutip metode pengujian daya cerna protein secara in vitro yang dilakukan oleh Saunders et al. (1973). Enzim yang digunakan dalam penelitian ini adalah enzim tripsin (sigma), kimotripsin (sigma), dan pankreatin (sigma). Pengujian daya cerna protein secara in vitro dimulai dengan pencampuran bahan dengan penambahan buffer fosfat pH 8,00 pada sampel konsentrat protein kacang merah dan kacang hijau agar menciptakan suasana basa. Setelah homogen, $10 \mathrm{~mL}$ larutan dicampurkan dengan $1,0 \mathrm{~mL}$ larutan multienzim $(1,6 \mathrm{mg}$ tripsin, $3,1 \mathrm{mg}$ kimotripsin, dan $4 \mathrm{mg}$ pankreatin). Proses inkubasi larutan sampel dilakukan pada suhu $30^{\circ} \mathrm{C}$ selama 10 menit untuk agar enzim dapat memecah protein. Pengukuran absorbansi menggunakan spektrofotometer UV-9200 (Rayleigh, Cina) pada panjang gelombang $578 \mathrm{~nm}$ dilakukan untuk menentukan daya cerna protein. Pengukuran absorbansi dilakukan dengan menggunakan indikator yaitu pereaksi folin ciocalteau yang memberikan perbedaan intensitas warna pada asam amino dan peptida hasil hidrolisis enzimatis dalam sampel. Daya cerna protein per kadar protein bubuk konsentrat protein kering (DCP) (\%) dapat dihitung menggunakan rumus:

$$
\mathrm{DCP}(\%)=\frac{100 \%}{\% \text { kadar protein bubu konsentrat protein }} \times
$$

$\left(\frac{\text { absorbansi sampel-absorbansi blanko sampel }}{\text { absorbansi kontrol-absorbansi blanko kontrol }}\right) \times 100 \%$ (1)

\section{HASIL DAN PEMBAHASAN}

\section{Kadar protein konsentrat protein kacang merah dan kacang hijau}

Isolasi protein pada prinsipnya didasarkan atas dua proses utama yaitu ekstraksi dengan pelarut basa dan pengendapan dengan pelarut asam (HattiKaul dan Mattiasson, 2011). Asam amino dapat bermuatan positif pada $\mathrm{pH}$ rendah, sedangkan pada $\mathrm{pH}$ tinggi dapat bermuatan negatif. Pada $\mathrm{pH}$ isoelektrik, asam amino berada pada keadaan dipolar atau in zwitter (Salgin et al., 2012). Kelarutan protein bernilai paling kecil pada keadaan tersebut sehingga protein akan menggumpal dan mengendap (Kusumah et al., 2020a). Perlakuan kondisi ekstraksi protein kacang merah dan kacang hiijau yang bervariasi memberikan hasil nilai kadar protein yang berbeda. 
Berdasarkan Tabel 1, dapat dilihat bahwa kisaran nilai kadar protein per total solid endapan

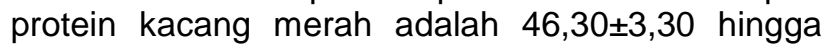
$93,20 \pm 0,87 \%$, sedangkan untuk endapan kacang hijau adalah $71,97 \pm 7,78$ hingga $92,44 \pm 0,27 \%$. Hasil ini menunjukkan bahwa kondisi ekstraksi protein kacang merah dan kacang hijau memberikan kadar protein yang berbeda-beda. Menurut Wang et al. (2011), endapan protein kacang hijau tertinggi dihasilkan pada suhu ekstraksi $31,74^{\circ} \mathrm{C}, \mathrm{pH} 8,97$, lama ekstraksi 33,24 menit dan menghasilkan rendemen protein $77,60 \%$. Penelitian lain menyebutkan bahwa kondisi ekstraksi yang optimal untuk ekstraksi protein kacang hijau adalah pada suhu $40^{\circ} \mathrm{C}$, $\mathrm{pH} 9,10$ dan menghasilkan rendemen protein $77,32 \%$ (Du et al., 2017).

Hasil analisis model optimasi (Tabel 2), menunjukkan bahwa model yang terpilih adalah kuadratik, karena model ini yang memiliki $R^{2}$ mendekati 1 yaitu 0,8432 untuk kacang merah dan 0,8354 untuk kacang hijau. Model kuadratik dipilih karena menunjukkan nilai yang signifikan $(P<0,05)$ yaitu 0,0363 (kacang merah) dan 0,0420 (kacang hijau). Nilai lack of fit endapan protein menunjukkan tidak signifikan $(P>0,05)$ yaitu 0,8411 (kacang merah) dan 0,7405 (kacang hijau).

Hasil analisis ragam (ANOVA) didapatkan secara otomatis dengan menggunakan menu fit summary dalam program Desain Expert 10. Model optimasi pada endapan protein kacang merah memiliki nilai $P<0,05$ yaitu 0,0363 artinya siginifikan. Pada variabel A (suhu ekstraksi) memiliki nilai $P<0,05$ yaitu 0,0008 yang berarti siginifikan. Berdasarkan hasil tersebut maka variasi perlakuan suhu $\left(30-50^{\circ} \mathrm{C}\right)$ dalam proses ekstraksi protein kacang merah dapat berpengaruh terhadap respon kadar protein endapan protein kacang merah. Hal ini di- sebabkan karena daya ikat air menurun seiring dengan proses pemanasan yang membuat protein menjadi terdenaturasi (Andoyo et al., 2015). Pemanasan juga dapat memberikan keuntungan yaitu menginaktifkan atau menurunkan protein inhibitor. Pemanasan juga dapat meniminalkan alergenitas pada kacang (Palupi et al., 2015). Perlakuan pemanasan dapat memengaruhi sifat gelasi pada protein (Morand et al., 2011). Perlakuan pH ekstraksi dan lama ekstraksi tidak berpengaruh terhadap respon kadar protein endapan protein kacang merah. Variabel $\mathrm{pH}$ ekstraksi dan lama ekstraksi memiliki nilai tidak signifikan $(P>0,05)$ yaitu masing-masing 0,6168 dan 0,5058.

Pada sampel kacang hijau, model optimasi pada endapan protein kacang hijau memiliki nilai $P<0,05$ yaitu 0,0420 artinya siginifikan. Pada variabel $A$ (suhu ekstraksi) dan variabel $B$ ( $\mathrm{pH}$ ekstraksi) memiliki hasil yang siginifikan. Berdasarkan hasil tersebut, variasi perlakuan suhu dan $\mathrm{pH}$ dalam proses ekstraksi protein kacang hijau dapat berpengaruh terhadap respon kadar protein endapan protein kacang hijau. Jumlah protein lebih banyak dihasilkan pada kondisi basa karena protein yang terlarut lebih mudah dipisahkan dari residu. Kondisi basa juga dapat memberikan efek yang merugikan yaitu merusak asam amino yang mengandung belerang seperti lisin, metioni, triptopan, dan treonin (Kanetro, 2017). Variasi pH pada proses ekstraksi protein kacang memengaruhi kadar protein, kadar air, rendemen, kecerahan, daya serap air, daya serap minyak, kapasitas emulsi, stabilitas emulsi, kapasitas buih, serta stabilitas buih konsentrat protein kacang (Pratiwi et al., 2018). Variabel C (lama ekstraksi) tidak berpengaruh terhadap respon kadar protein endapan protein kacang hijau dengan nilai $P>0,05$ yaitu 0,1681 .

Tabel 2. Analisis model optimasi

\begin{tabular}{|c|c|c|c|c|c|}
\hline Sampel & Model & $\begin{array}{c}\text { Signifikansi } \\
(P<0,05)\end{array}$ & Lack of Fit & $\mathrm{R}^{2}$ & Model Matematika \\
\hline \multirow[t]{3}{*}{$\begin{array}{l}\text { Endapan protein } \\
\text { kacang merah }\end{array}$} & Kuadratik & 0,0363 & 0,8411 & 0,8432 & $\begin{array}{l}=74,15-18,67 A-1,74 B-2,33 C- \\
1,18 A B-0,017 A C+3,92 B C-8,53 A^{2} \\
+1,98 B^{2}+4,59 C^{2}\end{array}$ \\
\hline & Linear & 0,0006 & 0,8275 & 0,7264 & $Y=73,23-18,67 A-1,74-2,33 C$ \\
\hline & Kubik & 0,2281 & - & 0,8700 & $\begin{array}{l}Y=74,15-16,96 A-3,74 B-4,83 C- \\
1,18 A B-0,017 A C+3,92 B C-8,53 A^{2} \\
+1,98 B^{2}+4,59 C^{2}+4 A^{2} B+5,01 A^{2} C- \\
3,42 A B^{2}\end{array}$ \\
\hline \multirow[t]{3}{*}{$\begin{array}{l}\text { Endapan protein } \\
\text { kacang hijau }\end{array}$} & Kuadratik & 0,0420 & 0,7405 & 0,8354 & $\begin{array}{l}Y=87,24-3,62 A-4,43 B+1,92 C- \\
3,69 A B+3,05 A C+1,05 B C-2,26 A 2- \\
2,64 B 2+1,14 C 2\end{array}$ \\
\hline & Linear & 0,0135 & 0,4735 & 0,5483 & $Y=85,48-3,62 A-4,43 B+1,92 C$ \\
\hline & Kubik & 0,2125 & - & 0,8758 & $\begin{array}{l}Y=87,24-3,66 A-5,74 B+0,94 C- \\
3,69 A B+3,05 A C+1,05 B C-2,26 A^{2}- \\
2,64 B^{2}+1,14 C^{2}+2,62 A^{2} B+1,97 A^{2} C\end{array}$ \\
\hline
\end{tabular}

Keterangan: Faktor $\mathrm{A}=$ suhu ekstraksi $\left({ }^{\circ} \mathrm{C}\right)$; Faktor $\mathrm{B}=\mathrm{pH}$ ekstraksi; Faktor $\mathrm{C}=$ lama ekstraksi (menit) 
Berdasarkan grafik contour plot pada Gambar 1, menunjukkan bahwa nilai respon kadar protein endapan kacang merah dan kacang hijau ditentukan oleh kombinasi antar variabel suhu ekstraksi, pH ekstraksi, dan lama ekstraksi yang saling memengaruhi. Nilai respon terendah ditunjukkan dengan adanya warna biru pada grafik contour plot, yaitu kadar protein $46,30 \pm 3,30 \%$ (kacang merah) dan $71,97 \pm 7,78 \%$ (kacang hijau). Nilai respon tertinggi ditunjukkan dengan adanya warna merah pada grafik contour plot yaitu kadar protein $93,20 \pm 0,87 \%$ (kacang merah) dan $92,44 \pm 0,27 \%$ (kacang hijau). Program Desain Expert 10 juga dapat memberikan bentuk permukaan dalam tampilan grafik 3D agar

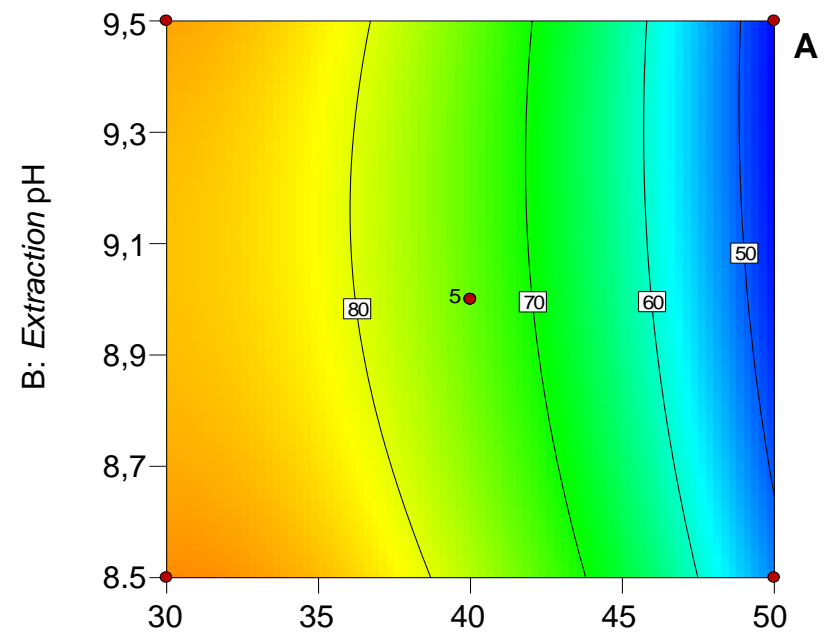

A: Extraction Temperature $\left({ }^{\circ} \mathrm{C}\right)$ dapat melihat lebih jelas hubungan interaksi antar variabel suhu ekstraksi, pH ekstraksi, dan lama ekstraksi dengan nilai respon kadar protein (Gambar 2). Sama seperti grafik contour plot, warna biru pada grafik menunjukkan nilai respon yang terendah, sedangkan warna merah menunjukkan nilai respon tertinggi.

Komponen pertama yang dioptimalkan adalah suhu ekstraksi dengan target minimal $30^{\circ} \mathrm{C}$ dan tingkat kepentingan $3+$ (Tabel 3). Penentuan ini dikarenakan proses pemanasan dapat memengaruhi karaktersitik protein kacang merah dan kacang hijau yaitu dengan terjadinya denaturasi protein (Andoyo et al., 2014).

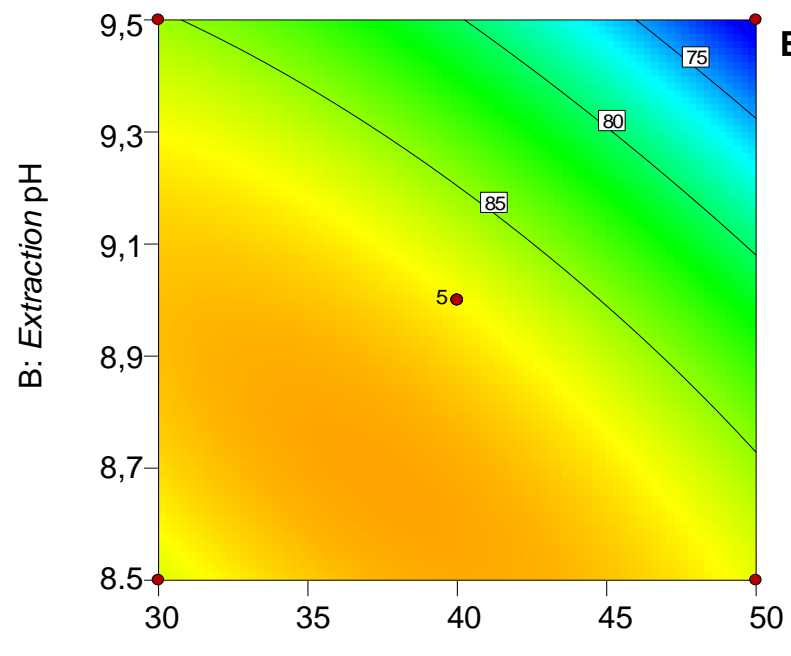

A: Extraction Temperature $\left({ }^{\circ} \mathrm{C}\right)$

Gambar 1. Grafik contour plot hasil uji respon kadar protein kacang merah (A) dan kacang hijau (B)
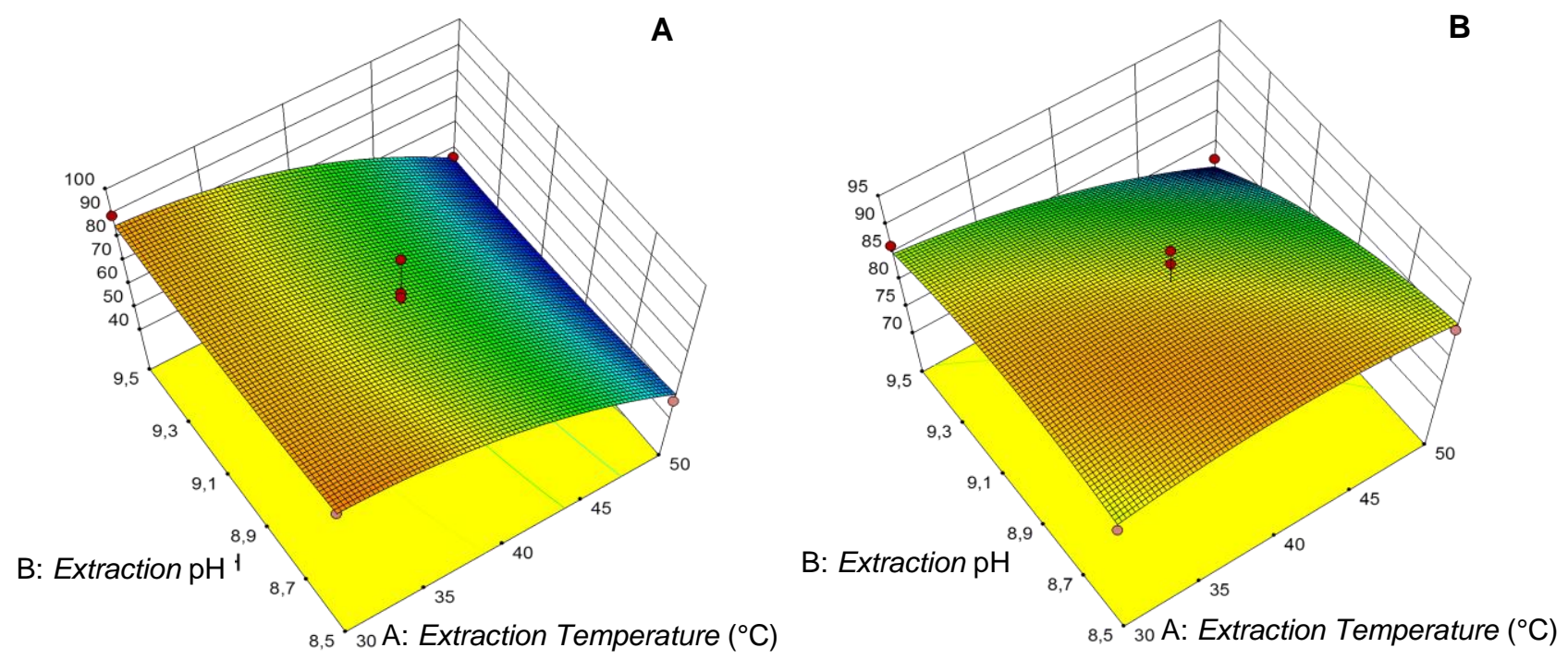

Gambar 2. Grafik tiga dimensi hasil uji respon kadar protein kacang merah (A) dan kacang hijau (B) 
Tabel 3. Komponen respon yang dioptimasi, target, batas, dan kepentingan pada tahapan optimasi formula

\begin{tabular}{lccccc}
\hline Sampel & Komponen Respon & Target/Goal & $\begin{array}{c}\text { Batas Bawah/ } \\
\text { Lower Limit }\end{array}$ & $\begin{array}{c}\text { Batas Atas/ } \\
\text { Upper Limit }\end{array}$ & $\begin{array}{c}\text { Kepentingan/ } \\
\text { Importance }\end{array}$ \\
\hline Endapan & Suhu ekstraksi $\left({ }^{\circ} \mathrm{C}\right)$ & Minimal/Minimum & 30 & 50 & $3+$ \\
protein & pH ekstraksi & kisaran/Inrange & 8,50 & 9,50 & $3+$ \\
kacang & Lama ekstraksi (menit) & kisaran/In range & 30 & 60 & $3+$ \\
merah & Protein per Total Solid (\%) & Maksimal/Maximum & 46,30 & 93,20 & $5+$ \\
\hline Endapan & Suhu ekstraksi $\left({ }^{\circ} \mathrm{C}\right)$ & Minimal/Minimum & 30 & 50 & $3+$ \\
protein & pH ekstraksi & kisaran/In range & 8,50 & 9,50 & $3+$ \\
kacang & Lama ekstraksi (menit) & kisaran/In range & 30 & 60 & $3+$ \\
hijau & Protein per Total Solid (\%) & Maksimal/Maximum & 71,97 & 92,44 & $5+$ \\
\hline
\end{tabular}

$\mathrm{pH}$ ekstraksi merupakan komponen kedua yang dioptimalkan dengan target kisaran 8,50-9,50 dan tingkat kepentingan $3+$. Penentuan ini dikarenakan pada kondisi basa dapat memberikan protein yang lebih banyak tetapi dapat juga merusak asam amino yang mengandung belerang (Kanetro, 2017). Lama ekstraksi merupakan komponen ketiga yang dioptimalkan dengan tingkat kepentingan 3+ dan memiliki kisaran 30-60 menit. Penentuan ini dikarenakan ikatan peptida dapat terhidrolisis dan menguraikan struktur primer protein yang dipengaruhi oleh lama protein bereaksi dengan asam maupun basa (Lafarga et al., 2018).

Respon yang dioptimalkan yaitu kadar protein dengan tingkat kepentngan $5+$ dan ditargetkan memiliki nilai maksimal. Tingkat kepentingan dengan nilai 5 dipilih karena proses optimasi proses ekstrasi protein harus menghasilkan kadar protein semaksimal mungkin. Konsentrat protein kacang-kacangan harus mengandung protein sedikitnya $70 \%$, sedangkan isolat protein harus mengandung lebih dari $90 \%$ protein dari bahan kering (Kanetro, 2017).

Optimasi proses ekstraksi protein kacang merah dan kacang hijau mendapatkan nilai respon kadar protein dengan melihat nilai desirability. Berdasarkan proses optimasi, program Desain Expert 10 memberikan 10 (sepuluh) solusi formula optimum (Tabel 4). Kondisi proses ekstraksi protein kacang merah yang direkomendasikan sebagai solusi optimal adalah dengan suhu ekstraksi $30^{\circ} \mathrm{C}, \mathrm{pH}$ ekstraksi 8,60 dan lama ekstraksi 30,1 menit. Pada kondisi tersebut memiliki nilai desirability yang tinggi yaitu sebesar 1,000 dan diprediksi menghasilkan kadar protein per total solid tertinggi yaitu $95,99 \%$. Hasil berbeda ditunjukkan pada proses ekstraksi protein kacang hijau, solusi formula optimal yang direkomendasikan yaitu kondisi proses ekstraksi protein dengan suhu ekstraksi $30^{\circ} \mathrm{C}, \mathrm{pH}$ ekstraksi 8,83 dan lama ekstraksi 30,0 menit. Kondisi tersebut menghasilkan nilai desirability yang tinggi dengan nilai 0,961 dan diprediksi menghasilkan kadar protein per total solid tertinggi yaitu $91,17 \%$.

Verifikasi atau validasi data dilakukan untuk memverifikasi tingkat kebenaran model yang direko- mendasikan oleh program Desain Expert 10 (Tabel 5). Hasil uji laboratorium (nilai aktual) menunjukkan kadar protein per total solid pada endapan kacang merah sebesar $86,88 \pm 1,38 \%$ sedangkan nilai prediksi adalah $95,39 \%$. Endapan protein kacang hijau memiliki kandungan protein sebesar $88,27 \pm 1,08 \%$, sedangkan prediksi Desain Expert adalah 91,17\%. Adapun nilai validitas pada endapan protein kacang merah dan kacang hijau masing-masing adalah 0,91 dan 0,97 . Optimasi proses isolasi kacang merah dan kacang hijau memiliki nilai validasi mendekati 1 . Berdasarkan hasil tersebut maka kondisi proses optimum yang direkomendasikan oleh program Desain Expert memiliki tingkat kebenaran yang tinggi dan dapat dipercaya.

Endapan protein kacang merah dan kacang hijau terbaik yang dihasilkan pada kondisi optimum kemudian dikeringkan menggunakan teknik freeze drying agar menghasilkan bubuk konsentrat protein kering. Pemilihan metode freeze drying dalam proses pengeringan bertujuan untuk menghindari protein dari kerusakan akibat suhu tinggi (Coscueta et al., 2019; Du et al., 2017).

Berat bubuk konsentrat protein kacang merah yang dihasilkan dari $40 \mathrm{~g}$ tepung kacang merah adalah 5,95 g, sehingga rendemen berat konsentrat protein kacang merah ada-lah $14,88 \%$. Isolasi protein tepung kacang hijau menghasilkan rendemen berat sebesar $16,75 \%$ dengan berat bubuk konsentrat protein kacang hijau yang dihasilkan sebesar 6,70 g.

\section{Kadar air konsentrat protein kacang merah dan kacang hijau terhidrolisis enzimatis}

Proses hidrolisis enzimatis pada konsentrat protein kacang merah dan kacang hijau menggunakan enzim bromelin yang memiliki aktivitas enzim yaitu 1260 GDU (Gelation Digestion Unit) atau setara dengan 0,455 U/g. Berdasarkan Tabel 6, bubuk konsentrat protein kacang merah dan kacang hijau yang terhidrolisis enzimatis memiliki kadar air berturut-turut $12,48 \pm 0,75$ dan $11,17 \pm 0,17 \%$. Mikroba dapat tumbuh pada bahan pangan dengan kadar air minimum sebesar $14-15 \%$. 
Tabel 4. Solusi formula optimum dan desirability

\begin{tabular}{lcccccc}
\hline \multicolumn{1}{c}{ Sampel } & No & $\begin{array}{c}\text { Faktor A } \\
\text { Suhu Ekstraksi } \\
\left({ }^{\circ} \text { C) }\right.\end{array}$ & $\begin{array}{c}\text { Faktor B } \\
\text { pH } \\
\text { Ekstraksi }\end{array}$ & $\begin{array}{c}\text { Faktor C } \\
\text { Lama Ekstraksi } \\
(\text { menit })\end{array}$ & $\begin{array}{c}\text { Respon Kadar Protein } \\
\text { per Total Solid }(\%)\end{array}$ & Desirability \\
\hline Endapan & 1 & 30 & 8,63 & 30,1 & 95,3925 & 1,000 \\
protein & 2 & 30 & 8,52 & 32,8 & 94,6425 & 1,000 \\
kacang & 3 & 30 & 8,52 & 33,3 & 94,2824 & 1,000 \\
merah & 4 & 30 & 8,60 & 31,4 & 94,6581 & 1,000 \\
& 5 & 30 & 8,80 & 30,0 & 93,2929 & 1,000 \\
& 6 & 30 & 8,76 & 30,6 & 93,2676 & 1,000 \\
& 7 & 30 & 8,56 & 32,9 & 94,0185 & 1,000 \\
& 8 & 30 & 8,57 & 31,4 & 95,0558 & 1,000 \\
& 9 & 30 & 8,60 & 30,1 & 95,9995 & 1,000 \\
Endapan & 1 & 30 & 8,75 & 30,1 & 93,8866 & 1,000 \\
protein & 2 & 30 & 8,83 & 30,0 & 91,1737 & 0,961 \\
kacang hijau & 3 & 30 & 8,83 & 30,0 & 91,1735 & 0,961 \\
& 4 & 30 & 8,83 & 30,0 & 91,1735 & 0,961 \\
& 5 & 30 & 8,82 & 30,0 & 91,1729 & 0,961 \\
& 6 & 30 & 8,84 & 30,0 & 91,1705 & 0,961 \\
& 7 & 30 & 8,81 & 30,0 & 91,1694 & 0,961 \\
& 8 & 30 & 8,81 & 30,0 & 91,1680 & 0,961 \\
& 9 & 30 & 8,85 & 30,0 & 91,1379 & 0,961 \\
\end{tabular}

Tabel 5. Validasi solusi formula optimum

\begin{tabular}{|c|c|c|c|c|c|c|}
\hline \multirow[t]{2}{*}{ Sampel } & \multirow{2}{*}{$\begin{array}{c}\text { Faktor A } \\
\text { Suhu Ekstraksi } \\
\left({ }^{\circ} \mathrm{C}\right)\end{array}$} & \multirow[t]{2}{*}{$\begin{array}{l}\text { Faktor B } \\
\text { pH Ekstraksi }\end{array}$} & \multirow{2}{*}{$\begin{array}{c}\text { Faktor C } \\
\text { Lama Ekstraksi } \\
\text { (menit) }\end{array}$} & \multicolumn{2}{|c|}{$\begin{array}{l}\text { Respon Kadar Protein per } \\
\text { Total Solid (\%) }\end{array}$} & \multirow[t]{2}{*}{ Validitas } \\
\hline & & & & Nilai Aktual & Nilai Prediksi & \\
\hline $\begin{array}{l}\text { Endapan protein } \\
\text { kacang merah }\end{array}$ & 30 & 8,60 & 30,1 & $86,88 \pm 1,38$ & 95,39 & 0,91 \\
\hline $\begin{array}{l}\text { Endapan protein } \\
\text { kacang hijau }\end{array}$ & 30 & 8,83 & 30,0 & $88,27 \pm 1,08$ & 91,17 & 0,97 \\
\hline
\end{tabular}

Tabel 6. Data kadar air dan kadar protein bubuk konsentrat protein terhidrolisis enzimatis

\begin{tabular}{lcc}
\hline \multicolumn{1}{c}{ Sampel } & $\begin{array}{c}\text { Kadar Air } \\
(\%)\end{array}$ & $\begin{array}{c}\text { Kadar } \\
\text { Protein (\%) }\end{array}$ \\
\hline $\begin{array}{l}\text { Bubuk konsentrat protein } \\
\text { kacang merah }\end{array}$ & $12,48 \pm 0,75$ & $78,43 \pm 0,67$ \\
terhidrolisis enzimatis & & \\
$\begin{array}{l}\text { Bubuk konsentrat protein } \\
\text { kacang hijau terhidrolisis } \\
\text { enzimatis }\end{array}$ & $11,17 \pm 0,17$ & $88,77 \pm 0,20$ \\
\hline
\end{tabular}

Konsentrat protein kacang merah dan kacang hijau mengandung protein amfifatik yaitu adanya gugus asam amino hidrofilik (dapat berikatan dengan air) pada bagian luar dan gugus hidrofobik pada bagian dalam (Pangastuti et al., 2013). Kandungan air konsentrat protein dipengaruhi oleh asam amino yang bersifat polar seperti asam glutamat, asam aspartat, lisin, arginin dan histidin yang mampu mengikat air (Pratiwi et al., 2018). Nilai activity water $\left(\mathrm{a}_{\mathrm{w}}\right)$ juga memengaruhi daya tahan bahan pangan terhadap serangan mikroba. $a_{w}$ adalah jumlah air bebas yang digunakan mikroba untuk melakukan pertumbuhannya. Semakin kecil nilai kadar air produk, maka semakin kecil pula nilai $a_{w}$ produk tersebut (Rizqiati et al., 2020). Berdasarkan hasil tersebut maka bubuk konsentrat protein kacang merah dan kacang hijau dengan modifikasi hidrolisis enzimatis memiliki karakteristik kadar air yang baik.

\section{Kadar protein konsentrat protein kacang merah dan kacang hijau terhidrolisis enzimatis}

Berdasarkan Tabel 6, bubuk konsentrat protein kacang merah dan kacang hijau terhidrolisis enzimatik memiliki kadar protein berturut-turut yaitu $78,43 \pm 0,67$ dan $88,77 \pm 0,20 \%$. Beberapa penelitian lain menghasilkan bubuk konsentrat protein kacang merah terhidrolisis enzimatis dengan kandungan protein sebesar $73,34 \%$ (Liu et al., 2011) dan 80,8\% (Al-Ruwaih et al., 2018). Kadar protein bubuk konsentrat protein kacang merah dan kacang hijau lebih tinggi dibandingkan dengan hasil penelitian lainnya. Hal ini bisa disebabkan karena lama hidrolisis yang lebih pendek (60 menit) dibandingkan dengan penelitian lainnya (3,5-4 jam). Semakin lama protein bereaksi dengan asam atau basa kemungkinan besar ikatan peptida terhidrolisis sehingga struktur primer protein terurai (Lafarga et al., 2018). 
Kandungan protein pada bubuk konsentrat protein kacang merah dan kacang hijau terhidrolisis enzimatis dapat dimanfaatkan untuk memperbaiki kualitas produk pangan atau sebagai ingredient fungsional. Jumlah asam amino hidrofilik dan hidrofobik mengendalikan sifat-sifat kelarutan, potensial pengikatan air, dan sifat-sifat permukaan (Houde et al., 2018). Perlakuan hidrolisis enzimatis dapat meningkatkan kapasitas pengemulsian protein, meningkatkan kelarutan protein, dan menurunkan kapasitas penyerapan air dan minyak (Kanetro, 2017).

\section{Daya cerna protein konsentrat protein kacang merah dan kacang hijau terhidrolisis enzimatis}

Berdasarkan Gambar 3, bubuk konsentrat protein kacang merah dan kacang hijau memiliki daya cerna protein metode in vitro yaitu masing-masing $4,36 \pm 0,08$ dan $4,45 \pm 0,20 \%$. Pengujian daya cerna protein juga dilakukan pada bubuk konsentrat protein kacang merah dan kacang hijau terhidrolisis enzimatis yang menghasilkan nilai daya cerna protein jauh lebih tinggi yaitu masing-masing 19,97士 0,37 dan $18,96 \pm 0,14 \%$.

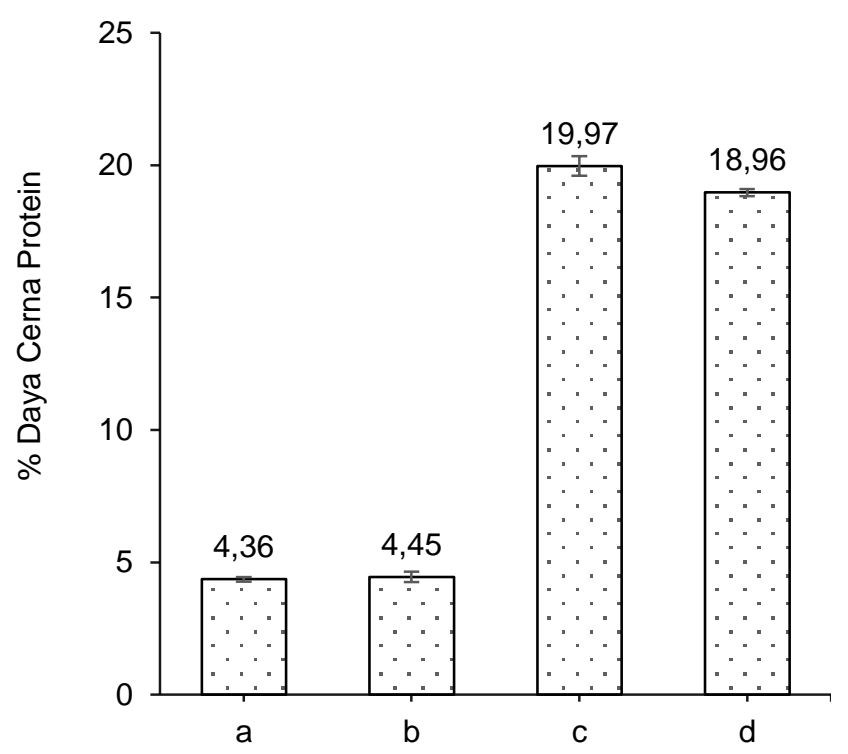

Keterangan: $a=$ Bubuk konsentrat protein kacang merah, $b=$ Bubuk konsentrat protein kacang hijau, $c=$ Bubuk konsentrat protein kacang merah terhidrolisis enzimatik, dan $d=$ Bubuk konsentrat protein kacang hijau terhidrolisis enzimatis

\section{Gambar 3. Daya cerna protein}

Terjadi peningkatan daya cerna protein pada konsentrat protein kacang merah dan kacang hijau terhidrolisis enzimatis. Hal ini mungkin disebabkan karena sebagian besar protein konsentrat tersebut sudah dihidrolisis oleh enzim bromelin pada proses hidrolisis enzimatis. Struktur protein dari konsentrat protein kacang merah dan kacang hijau terhidrolisis enzimatis diduga sudah terurai menjadi oligopeptida, tripeptida, dipeptida, atau asam amino (Cai et al., 2014). Perlakuan pemanasan selama proses hidrolisis juga dapat meningkatkan daya cerna protein kacang (Ren et al., 2018). Hal ini menyebabkan enzim tripsin dan kimotripsin bekerja lebih cepat pada bubuk kosentrat protein terhidrolisis enzimatis sehingga menghasilkan nilai daya cerna yang tinggi.

Daya cerna protein bubuk konsentrat protein kacang merah dan kacang hijau dapat ditingkatkan dengan cara menghilangkan lemak atau minyak pada bahan baku tepung kacang merah dan kacang hijau. Inhibitor berupa minyak (fase lipid) dapat menghalangi kontak protein dan enzim (fase aqueous) yang menyebabkan afinitas substrat terhadap sisi katalitik enzim menjadi rendah (Restiani, 2016). Peningkatan konsentrasi dan aktivitas enzim bromelin dapat dilakukan untuk menyempurnakan proses hidrolisis enzimatis pada bubuk konsentrat protein kacang merah dan kacang hijau (Kahiro et al., 2017). Penggunaan jenis enzim protease yang lain selama proses hidrolisis enzimatis juga dapat dicoba untuk mengetahui perbedaan daya cerna protein konsentrat protein kacang merah dan kacang hijau. Beberapa enzim lain yang dapat digunakan adalah alcalase, flavourzyme, pepsin, pankreatin, kimotripsin, papain, tripsin, dan thermolisin (Luna-Vital et al., 2014).

Peptida bioaktif memiliki peranan penting sebagai bahan pangan fungsional diantaranya adalah sebagai antihipertensi, antioksidan, antimikroba, antitrombotik, dan lain sebagainya (Tamam et al., 2018). Budseekoad et al. (2018) telah menghidrolisis protein kacang hijau dan menghasilkan oligopeptida dengan sifat calcium and iron-binding yang tersusun atas sekuen asam amino Leu-Leu-Leu-GlyIle, Ala-Ile-Val-Ile-Leu, dan His-Ala-Asp-Ala-Asp. Oligopeptida tersebut mengandung asam amino esensial dan memiliki sifat pengikat kalsium dan besi sebagai penunjang pertumbuhan dan jaringan tubuh.

Pangan tinggi protein yang mengandung banyak asam amino esensial dibutuhkan untuk proses pertumbuhan anak-anak. Pertumbuhan pada anakanak tergantung pada lempeng pertumbuhan chondral (Baron et al., 2015). Pertumbuhan tulang dan lempeng chondral diatur oleh mTORC1 dan kesediaan asam amino seperti leusin dan lisin (Efeyan et al., 2015). Apabila mTORC1 kekurangan asam amino maka dapat menekan untuk melakukan sintesis protein dan lipid (Laplante dan Sabatini, 2013). Anak yang kekurangan asupan asam amino esensial dapat memiliki risiko tinggi menjadi anak stunting. Berdasarkan hal tersebut, konsentrat protein kacang merah dan kacang hijau terhidrolisis enzimatik dapat direkomendasikan sebagai sumber protein dan asam amino esensial yang dibutuhkan penderita stunting. 


\section{KESIMPULAN}

Kondisi optimum proses ekstraksi protein kacang merah yaitu pada suhu $30^{\circ} \mathrm{C}$ dan $\mathrm{pH} 8,60$ selama 30,1 menit yang memiliki kadar protein $86,88 \pm$ $1,38 \%$ dengan nilai validitas 0,91 . Kondisi optimum proses ekstraksi protein kacang hijau yaitu pada suhu $30^{\circ} \mathrm{C}$ dan $\mathrm{pH} 8,83$ selama 30 menit yang memiliki kadar protein $88,27 \pm 1,08 \%$ dengan nilai validitas 0,97 . Proses modifikasi hidrolisis enzimatis menggunakan enzim bromelin mampu meningkatkan daya cerna protein bubuk konsentrat protein kacang merah dan kacang hijau sebesar 15,61 dan $14,51 \%$.

\section{DAFTAR PUSTAKA}

Al-Ruwaih N, Ahmed J, Mulla MF, Arfat YA. 2018. High-pressure assisted enzymatic proteolysis of kidney beans protein isolates and characterization of hyrolysates by functional, structural, rheological, and antioxidant properties. LWTFood Sci Technol 100: 231-236. DOI: 10.1016/j. Iwt.2018.10.074.

Almatsier S. 2013. Prinsip Dasar IImu Gizi. 77-104. PT. Gramedia Pustaka Utama, Jakarta.

Andoyo R, Guyomarc'h F, Burel A, Famelart M. 2015. Spatial arrangement of casein micelles and whey protein aggregate in acid gels: Insight on mechanisms. Food Hydrocoll 51: 118-128. DOI: 10.1016/j.foodhyd.2015.04.031.

Andoyo R, Guyomarc'h F, Cauty C, Famelart M-H. 2014. Model mixtures evidence the respective roles of whey protein particles and casein micelles during acid gelation. Food Hydrocoll 37: 203-212. DOI: 10.1016/j.foodhyd.2013.10.019.

Anihouvi V, Saalia F, Sakyi-Dawson E, Ayernor G, Hounhouigan J. 2011. Response surface methodology for optimizing the fermentation conditions during the processing of cassava fish (Pseudoolithus sp) into Lanhouin. Int J Eng Sci Technol 3: 7085-7095.

[AOAC] Association of Official Analytical Chemists. 1990. Official Methods of Analysis (Volume 1). AOAC, Arlington, Virginia.

Apriliyanti MW, Suryanegara MA, Wahyono A, Djamila S. 2020. Kondisi optimum perlakuan awal dan pengeringan kulit buah naga kering. $J$ Teknol Industri Pangan 31: 155-163. DOI: 10. 6066/jtip.2020.31.2.155.
Baron J, Sävendahl L, de Luca F, Dauber A, Phillip M, Wit JM, Nilsson O. 2015. Short and tall stature: A new paradigm emerges. Nat Rev Endocrinol 11: 735-746. DOI: 10.1038/nrendo. 2015.165.

Braimah MN, Anozie AN, Odejobi OJ. 2016. Utilization of response surface methodology (RSM) in the optimization of crude oil refinery. $J$ Multidiscip Eng Sci Technol 3: 4361-4369.

Budseekoad S, Yupanqui CT, Sirinupong N, Alashi AM, Aluko RE, Youravong W. 2018. Structural and functional characterization of calcium and iron-binding peptides from mung bean protein hydrolysate. J Funct Foods 49: 333-341. DOI: 10.1016/j.jff.2018.07.041.

Cai M-Y, Gu R-Z, Li C-Y, Ma Y, Dong Z, Liu W-Y, Jin Z-T, Lu J, Yi W-X. 2012. Pilot-scale production of soybean oligopeptides and antioxidant and antihypertensive effects in vitro and in vivo. J Food Sci Technol 51: 1866-1874. DOI: 10.1007/s13197-012-0701-4.

Coscueta ER, Campos DA, Osório H, Nerli BB, Pintado M. 2019. Enzymatic soy protein hydrolysis: A tool for biofunctional food ingredient production. Food Chem X 1: 100006. DOI: 10.1016/j.fochx.2019.100006.

Du M, Xie J, Gong B, Xu X, Tang W, Li X, Li, C. 2017. Extraction, physicochemical characteristics and functional properties of mung bean protein. Food Hydrocoll 76: 131-140. DOI: 10.101 6/j.foodhyd.2017.01.003.

Efeyan A, Comb WC, Sabatini DM. 2015. Nutrient sensing mechanisms and pathways. Nature 517: 302-310. DOI: 10.1038/nature14190.

Ernawati F, Prihatini M, Yuriestia A. 2016. Gambaran konsumsi protein nabati dan hewani pada anak balita stunting dan gizi kurang di Indonesia. Penelitian Gizi dan Makanan 39: 95102.

Gunarti DR, Rahmi H, Sadikin M. 2013. Isolation and purification of thiamine binding protein from mung bean. Hayati-J Biosci 20: 1-6. DOI: 10.4 308/hjb.20.1.1.

Hatti-Kaul R, Mattiasson B. 2011. Isolation and Purification of Proteins. In Handbook of Molecular and Cellular Methods in Biology and Medicine, Third Edition. Lund University Lund, Swedia.

Houde M, Khodaei N, Benkerroum N, Karboune S. 2018. Barley protein concentrates: Extraction, structural and functional properties. Food Chem 254: 367-376. DOI: 10.1016/j.foodchem.2018. 01.156 . 
Kahiro SK, Kagira JM, Maina N, Karanja SM, Njonge FN. 2017. Enzymatic activity of bromelain from crude extracts of crown, peels and stem of pineapples from different agro-ecological zones of thika region, Kenya. Asian J Biotechnol Bioresour Technol 1: 1-6. DOI: 10.9734/AJB2T/ 2017/34314.

Kanetro B. 2017. Teknologi Pengolahan dan Pangan Fungsional Kacang-Kacangan. 71-76 Palantaxia, Yogyakarta.

Kusumah SH, Andoyo R, Rialita T. 2020a. Isolation and characterization of red bean and green bean protein using the extraction method and isoelectric pH. SciMed J 2: 77-85. DOI: 10. 28991/SciMedJ-2020-0202-5.

Kusumah SH, Andoyo, R, Rialita T. 2020b. Protein isolation techniques of beans using different methods: A review. IOP Conference Series: Earth and Environmental Science 443, International Conference on Food and Bio-Industry 2019, 29-30 July 2019, Bandung, Indonesia. DOI: $10.1088 / 1755-1315 / 443 / 1 / 012053$.

Lafarga T, Álvarez C, Bobo G, Aguiló-Aguayo I. 2018. Characterization of functional properties of proteins from ganxet beans (Phaseolus vulgaris L. var. Ganxet) isolated using an ultrasound-assisted methodology. LWT-Food Sci Technol 98: 106-112. DOI: 10.1016/j.Iwt.2018. 08.033 .

Laplante M, Sabatini DM. 2012. mTOR signaling in growth control and disease. Cell 149: 274-293. DOI: 10.1016/j.cell.2012.03.017.

Liu Q, Jiang L, Li Y, Wang S, Wang M. 2011. Study on aqueous enzymatic extraction of red bean protein. Procedia Eng 15: 5035-5045. DOI: 10.1016/j.proeng.2011.08.936.

Luna-Vital DA, Mojica L, de Mejia EG, Mendoza S, Loarca-Pina G. 2014. Biological potential of protein hydrolysates and peptides from common bean (Phaseolus vulgaris L.): A review. Food Res Int 76: 39-50. DOI: 10.1016/j.foodres. 2014.11.024.

Maula A, Faridah DN, Muhandri T. 2019. Optimasi proses mi jagung varietas lokal dengan teknologi ekstrusi. J Teknol Industri Pangan 30: 110118. DOI: $10.6066 /$ jtip.2019.30.2.110.

Morand M, Guyomarch'h F, Famelart M-H. 2011. How to tailor heat-induced whey protein/kcasein complexes as a means to investigated the acid gelation of milk-a review. Dairy Sci Technol 91: 97-126. DOI: 10.1007/s13594-0110013-x.
Muhandri T, Subarna, Koswara S, Nurtama B, Ariefianto DI, Fatmala D. 2017. Optimasi pembuatan sohun ubi jalar menggunakan ekstruder pemasak-pencetak. J Teknol Industri Pangan 28: 36-45. DOI: 10.6066/jtip.2017.28.1.36.

Palupi NS, Sitorus SR, Kusnandar F. 2015. Perubahan alergenitas protein kacang kedelai dan kacang bogor akibat pengolahan dengan panas. J Teknol Industri Pangan 26: 222-231. DOI: 10.6066/jtip.2015.26.2.222.

Pangastuti HA, Affandi DR, Ishartani D. 2013. Karakteristik sifat fisik dan kimia tepung kacang merah (Phaseolus vulgaris L.) dengan beberapa perlakuan pendahuluan. J Teknosains Pangan 2: 20-29.

Pratiwi H, Yusasrini NLA, Putra INK. 2018. Pengaruh $\mathrm{pH}$ ekstraksi terhadap rendemen, sifat fisiko-kimia dan fungsional konsentrat protein kacang guide. J ITEPA 7: 1-11. DOI: 10.24843/ itepa.2018.v07.i01.p01.

Ren C, Xiong W, Peng D, He Y, Zhou P, Li J, Li B. 2018. Effect of thermal sterilization on soy protein isolate/polyphenol complexes: Aspects of structure, in vitro digestibility and antioxidant activity. Food Res Int 112: 284-290. DOI: 10. 1016/j.foodres.2018.06.034.

Restiani R. 2016. Hidrolisis secara enzimatis protein bungkil biji nyamplung (Calophyllum inophyllum) menggunakan bromelain. Biota 1: 103-110. DOI: 10.24002/biota.v1i3.1226.

Rizqiati $\mathrm{H}$, Nurwantoro, Febrisiantosa $A$, Shauma CA, Khasanah R. 2020. Pengaruh isolat protein kedelai terhadap karakteristik fisik dan kimia kefir bubuk. J Pangan Argoindustri 8: 111-121. DOI: 10.21776/ub.jpa.2020.008.03.1

Salgin S, Salgin U, Bahadir S. 2012. Zeta potentials and isoelectric points of biomolecules: The effect of ion types and ionic strengths. Int $\mathrm{J}$ Electrochem Sci 7: 12404-12414.

Saunders RM, Connor MA, Booth AN. 1973. Measurement of digestibility of alfalfa protein concentrates by in vivo and in vitro Methods. J Nutr 130: 530-535. DOI: 10.1093/jn/103.4.530.

Semba RD, Shardell M, Ashour FAS, Moaddel R, Trehan I, Maleta KM, Ordiz MI, Kraemer K, Khadeer MA, Ferrucci L, Manary MJ. 2016. Child stunting is associated with low circulating essential amino acids. EBioMed 6: 246-252. DOI: 10.1016/j.ebiom.2016.02.030.

Tamam B, Syah D, Lioe HN, Suhartono MT, Kusuma WA. 2018. Beberapa penciri berbasis sekuens untuk mengenali sifat fungsional peptida bioaktif: Studi eksplorasi. J Teknol Industri Pangan 29: 1-9. DOI: 10.6066/jtip.2018.29.1.1. 
Wang M, Jiang L, Li Y, Wang S, Sui X. 2011. Optimization of extraction process of protein isolate from mung bean. Procedia Eng 15: 5250-5258. DOI: 10.1016/j.proeng.2011.08.973.

Wang Q, Shi A, Liu H, Liu L, Zhang Y, Li N, Gong K, Yu M, Zheng L. 2016. Chapter 5-Peanut byproducts utilization technology. 211-236. Academic Press. DOI: 10.1016/B978-0-12-8095959.00005-3.
Yusuf AA, Komarulzaman A, Alisjahbana AS, Anna Z, Ghina AA, Setiawan A, Megananda. 2018. Seri Menyomgsong SDGs: Kesiapan Kabupaten/Kota di Provinsi Jawa Barat. Unpad Press, Bandung.

Zhu Y-S, Shuai S, FitzGerald R. 2018. Mung bean proteins and peptides: Nutritional, functional and bioactive properties. Food Nutr Res 62: 111. DOI: 10.29219/fnr.v62.1290. 